\title{
Students' entrepreneurial regulation and intention to become an entrepreneur: A comparison between public and private universities
}

\author{
Z.A.L. Pihie and A. Bagheri* \\ Department of Science and Technical Education, Faculty of Educational Studies, Universiti Putra Malaysia \\ Department of Entrepreneurship Development, Faculty of Entrepreneurship, Tehran University \\ zalp@upm.edu.my; bagheri 20052010@hotmail.com
}

\begin{abstract}
Motivation and ability to orient ones' knowledge, thought and behavior to accomplish entrepreneurial goals and tasks has recently termed as entrepreneurial regulation. Entrepreneurial regulation strongly affects the whole process of new venture creation and specifically entrepreneurial opportunity exploration that is the first step in the entrepreneurship process. However, few researchers examined the construct particularly among potential entrepreneurs such as university students. This study aims to measure self-regulation (promotion focus), entrepreneurial self-efficacy and intention to become an entrepreneur among university students. 722 students from both public and private universities were randomly selected as the participants based on the assumption that entrepreneurship education and training programs and university environment highly influence the development of entrepreneurial regulation, self-efficacy and intention in students. Analysis of the data revealed a significant relationship between students' promotion focus, entrepreneurial self-efficacy and entrepreneurial intentions. Furthermore, students from public universities had significantly higher entrepreneurial regulation and intentions than their counterparts from private universities. We discuss the implications of the findings for entrepreneurship research, theory development and education.
\end{abstract}

*To whom all correspondence should be addressed.

\section{Introduction}

The critical decision of choosing entrepreneurship as the career path and translating the intention into an actual new venture has been one of the core focuses of entrepreneurship researchers. To better explain this challenging and complex process, researchers used various theories and models, the most cited of which are intentional theories (Ajzen, 1991; Shapero \& Sokol, 1982). The rationale behind using these theories in entrepreneurship domain is that selection to startup ones' own business rather than being employed is basically a conscious and deliberate behavior that can be most accurately predicted by intention (Guerrero, Rialp \& Urbano, 2008; Souitaris, Zerbinati \& Al-Laham, 2007; Segal, Borgia \& Schoenfeld, 2005; Ajzen, 2002; Krueger, Reilly \& Carsrud, 2000; Boyd \& Vozikis, 1994). However, there is an unpredictable lag of time between the intention and creation of a real venture (Krueger et al., 2000; Krueger \& Brazeal, 1994). Moreover, entrepreneurial intention can be affected by personal and environmental factors and consequently changes over time (Souitaris et al., 2007; Segal et al., 2005; Ajzen, 2002; Krueger et al., 2000). This led researchers to seek more action-related theories such as self-regulatory focus (Higgins, 1998) to better explain entrepreneurial endeavors.

Based on the theory, Bryant (2007: 738) has recently termed "entrepreneurial-regulation"; the motivation and ability to orient ones' knowledge, thought and behavior to successfully accomplish entrepreneurial goals and tasks. Entrepreneurial regulation strongly affects the whole process of a new venture creation and specifically entrepreneurial opportunity exploration that is the first step in the entrepreneurship process (Tumasjan \& Braun (In press); Bryant, 2007). However, few researchers examined the construct and its association with entrepreneurial intention (Tumasjan \& Braun (In press); Trevelyan, 2011, Bryant, 2009, 2007), particularly among potential entrepreneurs such as university students. This study aims to narrow the gap through measuring entrepreneurial regulation dimensions (promotion focus and entrepreneurial self-efficacy) and entrepreneurial intention among university students. The findings expand the literature on students' entrepreneurial attributes by assessing entrepreneurial regulation, entrepreneurial self-efficacy and intention to become an entrepreneur. The following section of this paper briefly highlights the theoretical foundations of the entrepreneurial regulation construct and its association with entrepreneurial intention. Then, we present the research method and findings. Finally, we discuss main implications of our findings for entrepreneurship research, theory development and education.

\section{Entrepreneurial regulation: The theoretical and conceptual foundations}

The theory of self-regulation (Higgins, 1998) has recently attracted increasing attentions particularly in the entrepreneurship research. This is due to the power of the theory in explaining behaviours in complex and uncertain situations and stressing on the role that individuals can play in controlling and directing their behaviours toward their 
goal achievement. The theory is based on the belief that people consider the pleasant and beneficial outcomes when they set their personal goals and avoid uncomfortable situations (Higgins et al., 2001). In approaching their goal realization or task accomplishment, people act in two distinctive ways which are promotion and prevention focus. They are promotion focused when there are positive outcomes, gains and benefits in achieving their goals and prevention focused when there are negative outcomes, losses or failures in attaining their goals (Gorman et al., 2012; Brayant, 2007; Brockner, Higgins \& Low, 2004; McMullen \& Shepherd, 2002). Individuals' sense of selfregulation takes shape by a combination of their past success and failure experiences and situational factors which attract or compel them to direct their behaviors and achieve a specific goal (Higgins et al., 2001). Therefore, peoples' selfregulation differs in four main ways which are a) motivation and cognitive abilities to set personal goals; b) capability to organize the outcomes of the goals' accomplishment; c) the means and strategies they use to achieve the goals; and c) the situation in which they act (Trevelyan, 2011; Brayant, 2009, 2007; Brockner et al., 2004; McMullen \& Shepherd, 2002).

Researchers have recently applied self-regulatory theory in entrepreneurship domain to better explain entrepreneurial motivation and behavior (Gorman et al., 2012; Trevelyan, 2011; Brayant, 2009, 2007; Brockner et al., 2004). In particular, the theory has been used to describe the decision to pursue entrepreneurship as one's career (Bryant, 2006). In highly complex and risky situations such as entrepreneurship, self-regulation focus can be defined as the way individuals approach selection into entrepreneurship and direct their knowledge, thought and behavior to enact the intention and fulfill entrepreneurial tasks. Self-regulation and particularly promotion focus, therefore, affects the amount of efforts entrepreneurs put in establishing a new venture and performing entrepreneurial tasks and their success throughout the process of a new venture creation (Trevelyan, 2011; Brockner et al., 2004). In contrast, entrepreneurs with prevention focus avoid risky and uncertain tasks such as entering a new industry or market (Trevelyan, 2011). Scholars believe that entrepreneurs need both promotion and prevention focus for their challenging task performances (Brockner et al., 2004). However, empirical research findings indicate that entrepreneurs are more promotion focused specifically in exploring various creative and innovative opportunities for establishing their own ventures (Tumasjan \& Braun (In press); Trevelyan, 2011; Brockner et al., 2004), deciding on which entrepreneurial opportunities to exploit (Bryant, 2007) and improving the performance of their new venture (Hmieleski \& Baron, 2008).

Bandura (1997) argues that self-regulation focus affects ones' behavior through self-efficacy processes such as motivation to act, persistence in the face of problems and the sense of competence in accomplishing a task. Self-efficacy is the personal cognitive evaluation of one's ability to successfully perform a specific task. Entrepreneurial selfefficacy, therefore, is 'the belief in ones' efficacy in performing entrepreneurial tasks" (Brayant, 2007:735). Entrepreneurial self-efficacy improves individuals' motivation and competence in stepping into the challenging process of new venture creation (Boyd \& Vozikis, 1994). Based on the associations between entrepreneurs' promotion focus, self-efficacy and cognition capacity, Brayant (2007: 738 ) termed "entrepreneurial-regulation" construct in order to explain the common sources that inform entrepreneurial behavior. Although the author emphasizes that entrepreneurial regulation is not a new construct, research findings confirm the complementary nature of entrepreneurs' promotion focus and entrepreneurial selfefficacy (Tumasjan \& Braun (In press)). Through a metaanalysis of the researches on self-regulation dimensions, Gorman et al. (2012) conclude that promotion and prevention focus are two independent constructs each of which is related to other constructs of the relevant theories. Tumasjan and Braun (In press) examined the impact of regulation focus and entrepreneurial self-efficacy on opportunity recognition among 254 entrepreneurs. The researchers conclude that promotion focus enhances entrepreneurs' creative and entrepreneurial self-efficacy in the process of entrepreneurial opportunity recognition. Despite researchers' emphasize on integrating the two constructs (Brayant, 2009, 2007), as far as we know, there is no other study particularly in educational settings that looked at the strength of "entrepreneurial-regulation" in explaining entrepreneurial intention. Drawing upon Brayant's (2007) conceptualization, this study integrated and measured promotion focus and entrepreneurial selfefficacy among university students.

\section{Entrepreneurial regulation, entrepreneurial intention and entrepreneurship education}

The theory of self-regulation orientation (Higgins, 1998) has also been applied to explainthe critical role that education and training can play in improving students' self-regulation orientation and consequently their intention and competence to become an entrepreneur (Tumasjan \& Braun (In press); Bryant, 2006, 2007; Brockner et al., 2004; McMullen \& Shepherd, 2002). Researchers attempted to explore the relationship between entrepreneurs' self-regulation focus and their entrepreneurial behavior and related it to entrepreneurship education improvement (Tumasjan \& Braun (In press); Trevelyan, 2011; Bryant, 2006, 2007). Only few studies investigated the association between students' self-regulation focus and their entrepreneurial intentions. Using a sample of 142 business students, McMullen and Shepherd (2002) concluded that promotion focused students have higher entrepreneurial intentions than prevention focused ones. Therefore, educational methods for improving students' entrepreneurial self-regulation focus are yet to be developed (Brayant, 2007).

Despite the recent emergence of self-regulatory theory in the entrepreneurship education research (Bryant, 2006; McMullen \& Shepherd, 2002), there has been a tradition of using intentional theories such as theory of planed behavior (Ajzen, 1991) to explain the impact of entrepreneurship 
education on students' selection into entrepreneurship (e.g., Wu \& Wu, 2008; Souitaris et al., 2007; Fayolle, Gailly \& Lassas-Clerc, 2006; Zhao, Seibert \& Hills, 2005; Henry, Hills \& Leitch, 2005; Peterman\& Kennedy, 2003; Ajzen, 2002). The theory explains human decision to adopt a behavior such as new venture creation as a function of the interactions between three main motivational and enabling factors including control over behavior (individuals' perceptions of their abilities and skills to perform the tasks of an entrepreneur), attitude toward behavior (individuals' awareness of the importance and value of entrepreneurship) and subjective and social norms (individuals' perceptions toward how significant others value and support establishing a new business). Defining social norms as the widely accepted rules by groups of people, Meek, Pacheco and York (2010) concluded that such norms influence peoples' intention to establish their own businesses. Various educational programs have been developed to improve students' entrepreneurial intention and particularly through enhancing their self-efficacy in performing different roles and tasks of an entrepreneur (Kickul et al., 2009; Wu \& Wu, 2008; Wilson, Kickul \& Marlino, 2007; DePillis \& Reardon, 2007; Segal et al., 2005; DeNoble, Jung \& Ehrlich, 1999). Through engaging in the learning opportunities provided by the programs, students evaluate their capabilities in performing entrepreneurial tasks and decide on whether to pursue entrepreneurship as their future career path (Wilson et al., 2007; Fayolle et al., 2006; Zhao et al., 2005; Chen, Greene\& Crick. 1998).

Although the association between students' entrepreneurial intention and entrepreneurship education has been wellestablished in the entrepreneurship literature (Culbertson, Smith \& Leiva, 2011; Kickul et al., 2009; Souitaris et al., 2007; Fayolle et al., 2006; Zhao et al., 2005; Krueger et al., 2000; Chen et al., 1998), there is little knowledge about the impact of education on students' self-regulation focus and their intention to launch a new venture (McMullen \& Shepherd, 2002). Previous research findings showed the influential role played by self-regulation in entrepreneurs' decision making process (Bryant, 2007). However, the key role of self-regulation focus in the decision to become an entrepreneur and realization of the intention specifically among students has been almost overlooked. This lack of understanding face educators with critical challenges in providing effective education programs and pedagogical methods that improve students' self-regulation and entrepreneurial intention based on their strengths and weaknesses in each specific aspect of the constructs (Chen et al., 1998). This study aims to narrow the gap by measuring university students' entrepreneurial regulation and intention.

\section{Method}

Research design and measures

We employed a questionnaire consisting of 25 items to determine the level and pattern of self-regulation, entrepreneurial self-efficacy and entrepreneurial intentions among the participants. The questionnaire contained 4 main sections. The first section asked students' demographic information such as age, gender, level and field of study and university. The second section measured participants' promotion focus based on the Regulatory Focus questionnaire (Grant \& Higgins, 2003). Students' promotion focus was assessed through 6 items (e.g., Compared to most people, are you typically unable to get what you want out of life?). Five items of the Self-efficacy Skills questionnaire (Scherer et al., 1989) was administrated to measure students' self-efficacy in different tasks of an entrepreneur including marketing, accounting, organizing and personnel and production management (e.g., I can successfully complete the necessary marketing tasks related to owing a business: consider selling, selecting and customer service). The final section of the questionnaire assessed entrepreneurial activities. This section encompassed two subsections. First, students' desire and goal to pursue an entrepreneurial career (6 items), e.g., I am ready to do anything to be an entrepreneur and second, value of entrepreneurial activities for their family, friends and people in their community measured by 8 items, e.g., My immediate family values entrepreneurial activities and career (Ajzen \& Fishbein, 1980; Krueger et al., 2000).

\section{Sample}

The participants were 722 students who were randomly selected from five universities in Malaysia. The students were selected from both public and private universities based on the assumption that situational factors such as education highly affect individuals' sense of self-regulation, self-efficacy and entrepreneurial intention (Ajzen, 2002; Higgins et al., 2001; Bandura, 1997). Furthermore, the universities offer students different entrepreneurship education design, content and pedagogical methods and these differences affect students' entrepreneurial ability and intention improvement (Matlay, 2006). The students were asked to respond to the items of the questionnaire on a 5 point Likert scale, anchored from 1 "strongly disagree" to 5 "strongly agree". In terms of age, the majority of the students were in the rage of 16 to $25(76,9 \%)$ years old. Of the 722 participants, $377(52,2 \%)$ were male and $342(47,4 \%)$ were female. $391(54,2 \%)$ students were from private universities and 331(45,8\%) were from public universities. Most of the students were doing their Bachelors $541(74,9 \%)$. The students had different education backgrounds $(104(14,4 \%)$ doing education of agriculture science, $82(11,4 \%)$ information technology, 41(5,7\%) accounting and finance, and 495(68,5\%) others). Majority of the students had no business experiences 491(68\%). $363(50,3 \%)$ students had never taken an entrepreneurship course and $348(48,2 \%)$ had passed an entrepreneurship course previously.

\section{Findings}

Analysis of the data on self-regulation (promotion focus), entrepreneurial self-efficacy and entrepreneurial intention indicates that students scored moderate in all dimensions of the constructs (table 1). 
Table 1: Means, standard deviations and levels of the study variables

\begin{tabular}{|c|c|c|c|}
\hline Construct & Mean & SD & Level \\
\hline \multirow{3}{*}{$\begin{array}{l}\text { Entrepreneurial-regulation focus } \\
\text { - } \quad \text { Promotion focus } \\
\text { - } \quad \text { Entrepreneurial self- } \\
\quad \text { efficacy }\end{array}$} & 3,20 & 0,49 & \multirow{3}{*}{ Moderate } \\
\hline & 2,73 & 0,46 & \\
\hline & & 0,71 & \\
\hline - $\quad$ Entrepreneurial intentions & 3,09 & 0,52 & \multirow{2}{*}{ Moderate } \\
\hline - $\quad$ Social valuation & 3,01 & 0,57 & \\
\hline
\end{tabular}

Drawing upon Bryant's (2007) conceptualization and measurement of "entrepreneurial-regulation", we calculated an entrepreneurial regulation score for each student by adding their scores in promotion focus and entrepreneurial self-efficacy. Table 2 shows a significant difference between public and private university students in entrepreneurial regulation and intention. Although the number of students from private universities in the sample was more than the public university students, students from public university scored higher in entrepreneurial regulation $(t=-5,47$, sig $<0,00)$, entrepreneurial activities $(\mathrm{t}=-5,40, \quad$ sig $<0,00)$ entrepreneurial intention $(\mathrm{t}=-5,92, \operatorname{sig}<0,00)$, and social valuation $(\mathrm{t}=-5,87, \operatorname{sig}<0,00)$.

Table 2: t-test results for students' self-regulation, self-efficacy and intention based on type of university

\begin{tabular}{|c|c|c|c|c|c|}
\hline & Type of university & Mean & SD & t value & Sig \\
\hline Entrepreneurial regulation & $\begin{array}{l}\text { Public } \\
\text { Private }\end{array}$ & $\begin{array}{l}3,40 \\
3,20 \\
\end{array}$ & $\begin{array}{l}0,46 \\
0,47\end{array}$ & $-5,47$ & 0,00 \\
\hline Entrepreneurial activities & $\begin{array}{l}\text { Public } \\
\text { Private }\end{array}$ & $\begin{array}{l}3,35 \\
3,13\end{array}$ & $\begin{array}{l}0,51 \\
0,53\end{array}$ & $-5,40$ & 0,00 \\
\hline Entrepreneurial intentions & $\begin{array}{l}\text { Public } \\
\text { Private }\end{array}$ & $\begin{array}{l}3,32 \\
3,10\end{array}$ & $\begin{array}{l}0,49 \\
0,59\end{array}$ & $-5,92$ & 0,00 \\
\hline Social valuation & $\begin{array}{l}\text { Public } \\
\text { Private }\end{array}$ & $\begin{array}{l}3,27 \\
3,02\end{array}$ & $\begin{array}{l}0,56 \\
0,55\end{array}$ & $-5,87$ & 0,00 \\
\hline
\end{tabular}

Then, we correlated students' entrepreneurial regulation with their entrepreneurial intentions. As table 3 indicates there is a significant correlation between students' entrepreneurial regulation and their intention to become an entrepreneur $(r=0,57$, sig<0,00).

\section{Discussion}

The present study set out to determine self-regulation (promotion focus) and entrepreneurial self-efficacy based on the assumption that a combination of the constructs better explains entrepreneurial behavior (Bryant, 2007) and specifically entrepreneurial intention. On the importance of combining promotion focus and entrepreneurial selfefficacy, Bryant (2006:281) emphasizes that "Together, they cover the key attributes of self-regulation: self-reference, motivation systems, goal frameworks, and related affective and cognitive attributes". Therefore, students' entrepreneurial regulation reflects a wide range of their competence to become an entrepreneur. This study indicates that students scored moderate in both self-regulation and entrepreneurial self-efficacy. Since regulation focus is a function of both personal success and failure experiences as well as situational factors (Higgins et al., 2001), the moderate level of students' self-regulation may partially reflect their past experiences in achieving their goals and the environmental factors that affect the formation of a strong sense of promotion focus in them. With a moderate level of entrepreneurial regulation students are less likely to choose entrepreneurship as their career path, explore a new business idea and change it to a successful venture (Bryant, 2007; Brockner et al., 2004). This highlights an urgent need for improving students' promotion focus in order to motivate and enable them to successfully launch their own businesses. To do so, educators may need to enhance students' awareness of their regulation orientation and provide them various opportunities to experience real tasks and roles of an entrepreneur (Trevelyan, 2011; Bryant, 2009, 2007). Involvement in the process of establishing a new business and real entrepreneurial task practices not only help students to explore their ability in running a new business, but also enable them to consider the benefits of entrepreneurial activities for their personal growth and development (Trevelyan, 2011). Tumasjan and Braun (In press) emphasize the critical role that educators can play in adopting a promotion focused orientation and helping students to reflect on their entrepreneurial skills and learning and thereby enhancing their promotion focus. Educators can also improve students' ability to look at the benefits of entrepreneurial activities rather than the costs and losses of establishing a new business in order to improve their promotion focus (McMuller \& Sheperd, 2002). Therefore, entrepreneurship educators need to be well trained and equipped with the skills to design and implement the pedagogical methods that improve regulation focus of students. 
Table 3: Correlation between entrepreneurial regulation and entrepreneurial intention

\begin{tabular}{l|l|c|c}
\hline Variable & Entrepreneurial regulation & Entrepreneurial Intention \\
\hline Entrepreneurial regulation & $\begin{array}{l}\text { Pearson Correlation } \\
\text { Sig. (2-tailed) }\end{array}$ & 1 & $0,569^{* *}$ \\
\hline \multirow{2}{*}{ Entrepreneurial intention } & Pearson Correlation & 0,000 \\
\cline { 2 - 4 } & Sig. (2-tailed) & 0,000 & 1 \\
\hline
\end{tabular}

**. Correlation is significant at the 0,01 level (2-tailed).

Students' moderate level of entrepreneurial regulation can also be attributed to their perceptions toward their ability to successfully perform different tasks and roles of an entrepreneur. Being moderately efficacious in successfully fulfilling entrepreneurial tasks, students may not have sufficient motivation and ability to step into the process of entrepreneurship which involves various difficulties and uncertainties (Zhao et al., 2005). As emphasized by Chen et al. (1998) only students who have a strong confidence in their entrepreneurial skills have a high intention to become an entrepreneur. Entrepreneurship education can highly improve students' sense of entrepreneurial self-efficacy by engaging them in various learning opportunities such as business plan writing, role modeling and case study (Wilson et al., 2007; Fayolle et al., 2006; Chen et al., 1998). More importantly, entrepreneurship education can provide an encouraging and supporting environment in which students can run a real new venture and develop their entrepreneurial self-efficacy with less risk (Trevelyan, 2011; Fayolle \& Gailly, 2008; Fuchs, Werner \& Wallau, 2008; Pittaway \& Cope, 2007; Zhao et al., 2005). Providing experimental entrepreneurship learning opportunities for students is more urgent for Malaysian universities where entrepreneurship education has mostly focused on the theoretical aspects of the entrepreneurship process (Cheng, Chan \& Mahmood, 2009). Importantly, entrepreneurship education can benefit from the high association and "complementary" nature of the relationship between entrepreneurial self-efficacy and regulation focus (Tumasjan \& Barun (In press); Bryant, 2007). More established methods of self-efficacy development can be used to enhance students' regulatory orientation and specifically their promotion focus by focusing on successful goal achievement, challenging learning opportunities and experimental learning methods (Tumasjan \& Barun (In press); Heinonen, 2007; Wilson et al., 2007).

In addition, our findings revealed a significant difference between students from public and private universities in all the variables under this investigation. More specifically, students from public universities had a significant higher entrepreneurial regulation and intention to become an entrepreneur. This indicates entrepreneurship education and university environment in public universities were more effective in constructing a sense of regulation focus, entrepreneurial self-efficacy and intention among students. However, to become a successful entrepreneur, students need to have a high level of promotion focus (Tumasjan \& Barun (In press); Trevelyan, 2011; Bryant, 2006), a strong sense of efficacy in performing entrepreneurial tasks and great intentions to establish their own business (Kickul et al., 2009; Wilson et al., 2007; Fayolle et al., 2006). Therefore, entrepreneurship educators specifically in private universities need to provide various learning opportunities for students to experience different tasks of an entrepreneur since engagement in entrepreneurial tasks plays a dramatically critical role in enhancing students' selfregulation, entrepreneurial self-efficacy and intention (Trevelyan, 2011; Fayolle \& Gailly, 2008; Fuchs et al., 2008; Pittaway \& Cope, 2007; Zhao et al., 2005).

Particularly, Malaysian entrepreneurship educators need to focus more on experimental methods of entrepreneurship education rather than emphasizing on the theoretical aspects of entrepreneurship (Cheng et al., 2009; Mastura, Rashid \& Aziz, 2008). Furthermore, entrepreneurship education and training programs in Malaysia need to be integrated to the whole university curriculum and offered to students in all fields of studies through a coherent and comprehensive framework and structure (The World Bank, 2007). Finally, our findings indicate a significant relationship between entrepreneurial regulation and intention. This illustrates the influential impact of promotion focus and entrepreneurial self-efficacy on entrepreneurial intention and confirms the importance of improving students' entrepreneurial regulation in order to motivate and enable them to launch their own businesses.

\section{Conclusion}

In conclusion, our study provides support for "entrepreneurial-regulation" construct (Bryant, 2007) and its influential impact on university students' entrepreneurial intention. By measuring entrepreneurial regulation and intention among public and private university students as potential entrepreneurs, our findings demonstrate the entrepreneurial capacity of young generation in Malaysia. The moderate level of this capacity is alarming for both policy makers and educators who aim to change the nation to a developed leading country by the year 2020 (Mastura, Rashid \& Aziz, 2008). This study is the first of its kind that integrates promotion focus and entrepreneurial self-efficacy and relates it to students' intention to become an entrepreneur. Previous researchers looked at students' selfregulation and entrepreneurial intention (McMuller \& Sheperd, 2002) and entrepreneurial self-efficacy and intention (Wilson et al., 2007; Fayolle et al., 2006; Zhao et al., 2005; Chen et al., 1998). The use of entrepreneurial regulation and intention as factors that can be enhanced by education and training (Wilson et al., 2007; Bryant, 2006; Zhao et al., 2005; Henry et al., 2005; Chen et al., 1998) may 
provide a more helpful framework for researchers to explore entrepreneurial capabilities specifically among students.

Furthermore, a combination of the related constructs to entrepreneurial capabilities (entrepreneurial regulation and intention) may contribute to developing new theories about entrepreneurial behavior in particular for university students. Educators can assess these capabilities among students and identify those who possess these qualities and offer them more purposive and effective entrepreneurship education programs. In addition, measuring students' entrepreneurial regulation and intention help educators to improve their awareness of their strengths and weaknesses in each aspect of the constructs and provide them with appropriate learning opportunities and encouraging environments that enhance their entrepreneurial regulation and intention (Brockner et al., 2004). The synergy and complementary nature of regulatory focus and entrepreneurial self-efficacy can also help educators in providing more effective entrepreneurship education by focusing on the experimental methods of teaching entrepreneurship that can improve various entrepreneurial capabilities in students (Fuchs et al., 2008; Pittaway \& Cope, 2007; Zhao et al., 2005). This study opens new agendas for further investigations. Future longitudinal studies can be conducted to determine if students with high entrepreneurial regulation and intention ultimately launch their own businesses. In addition, exploring pedagogical methods that effectively improve students' entrepreneurial regulation has a great potential for further research. Developing such methods to enhance students' selfregulation focus has been emphasized by previous researchers (Bryant, 2007). Examining the existing methods of entrepreneurial self-efficacy education which can be applied in improving students' self-regulation focus can also be subjected to further studies.

\section{References}

Ajzen, I. 2002. 'Perceived behavioral control, self-efficacy, locus of control, and the theory of planned behaviour', Journal of Applied Social Psychology, 32:1-20.

Ajzen, I. 1991. 'The theory of planned behaviour', Organizational Behavior and Human Decision Processes, 50:179-211.

Ajzen, I. \& Fishbein, M. 1980. Understanding attitudes and predicting social behaviour. Englewood Cliffs, NJ: Prentice Hall.

Bandura, A. 1997. Self-efficacy: The exercise of control. W.H.Freeman and Company: New York.

Barbosa, S.D, Gerhardt, M.W. \& Kickul, J.R. 2007. 'The role of cognitive style and risk preference on entrepreneurial self-efficacy and entrepreneurial intentions', Journal of Leadership and Organizational Studies, 13(4):86-104.

Boyd, N.G. \& Vozikis, G.S. 1994. 'The influence of selfefficacy on the development of entrepreneurial intentions and actions', Entrepreneurship Theory and Practice, 118:63-90.

Brockner, J., Higgins, E.T. \& Low, M.B. 2004. 'Regulatory focus theory and the entrepreneurial process', Journal of Business Venturing, 19(2):203-220.

Bryant, P. 2009. 'Self-regulation and moral awareness among entrepreneurs', Journal of Business Venturing, 24:505-518.

Bryant, P. 2007. 'Self-regulation and decision heuristics in entrepreneurial opportunity evaluation and exploitation', Management Decision, 45(4):732-748.

Bryant, P. 2006. Improving entrepreneurial education through self-regulatory skills. The NCIIA, pp. 279-289.

Chen, C., Greene, P. \& Crick, A. 1998. 'Does entrepreneurial self-efficacy distinguish entrepreneurs from managers?' Journal of Business Venturing, 13:295-316.

Cheng, M.Y., Chan, W.S. \& Mahmood, A. 2009. 'The effectiveness of entrepreneurship education in Malaysia', Education + Training, 51(7):555-566.

Culbertson, S.S., Smith, M.R. \& Leiva, P.I. 2011. 'Enhancing entrepreneurship: The role of goal orientation and self-efficacy', Journal of Career Assessment, 19:115129.

DeNoble, A.F., Jung, D. \& Ehrlich, S.B. 1999. Entrepreneurial self-efficacy: The development of a measure and its relationship to entrepreneurial action. Waltham, MA: P\&R Publications Inc., pp 73-87.

DePillis, E. \& Reardon, K.K. 2007. 'The influence of personality traits and persuasive messages on entrepreneurial intention: A cross-cultural comparison', Career Development International, 12(4):382-396.

Fayolle, A. \& Gailly, B. 2008. 'From craft to science, teaching models and learning processes in entrepreneurship education', Journal of European Industrial Training, 32(7):569-593.

Fayolle, A., Gailly, B. \& Lassas-Clerc, N. 2006. 'Assessing the impact of entrepreneurship education programmes: A new methodology', Journal of European Industrial Training, 30(9):701-720.

Fuchs, K., Werner, A. \& Wallau, F. 2008. 'Entrepreneurship education in Germany and Sweden: What role do different school systems play?' Journal of Small Business and Enterprise Development, 15(2):365-381.

Grant, H. \& Higgins, E.T. 2003. 'Optimism, promotion pride, and prevention pride as predictors of quality of life', Personality \& Social Psychology Bulletin, 29(12):15211532. 
Gorman, C.A., Meriac, J.P., Overstreet, B.L., Apodaca, S., McIntyre, A.L., Park, P. \& Godbey, J.N. 2012. 'A metaanalysis of the regulatory focus nomological network: Work-related antecedents and consequences', Journal of Vocational Behavior, 80: 160-172.

Guerrero, M., Rialp, J. \& Urbano, D. 2008. 'The impact of desirability and feasibility on entrepreneurial intentions: A structural equation model', International Entrepreneurship Management Journal, 4:35-50.

Higgins, E.T., Friedman, R.S., Harlow, R.E., Idson, L.C., Ayduk, O.N. \& Taylor, A. 2001. 'Achievement orientations from subjective histories of success: Promotion pride versus prevention pride', European Journal of Social Psychology, 31(1):3-23.

Higgins, E.T. 1998. 'Promotion and prevention: Regulatory focus as a motivational principle', Advances in Experimental Social Psychology, 30:1-46.

Henry, C., Hill, F. \& Leitch, C. 2005. 'Entrepreneurship education and training: Can entrepreneurship be taught?' Education + Training, 47(2):98-111.

Heinonen, J. 2007. 'An entrepreneurial-directed approach to teaching corporate entrepreneurship at university level', Education + Training 49(4):310-324.

Hmieleski, K.M., Baron, R.A. 2008. 'Regulatory focus and new venture performance: a study of entrepreneurial opportunity exploitation under conditions of risk versus uncertainty', Strategic Entrepreneurship Journal, 2:285299.

Kickul, J., Gundry, L.K., Barbosa, S.D. \& Whitcanack, L. 2009. 'Intuition versus analysis? Testing differential models of cognitive style on entrepreneurial self-efficacy and the new venture creation process', Journal of Entrepreneurship Theory and Practice, 33(2):439-453.

Krueger, N.F., Reilly, M.D. \& Carsrud, A.L. 2000. 'Competing models of entrepreneurial intentions', Journal of Business Venturing, 15(5/6):411-432.

Krueger, N.F. \& Brazeal, D. 1994. 'Entrepreneurial potential and potential entrepreneurs', Entrepreneurship Theory \& Practice, 18(3): 91-104.

Matlay, H. 2006. 'Researching entrepreneurship and education. Part 2 What is entrepreneurship education and does it matter?' Education + Training, 48(8/9): 704-718.

Mastura, J. \& Rashid, A. \& Aziz, A. 2008. 'Entrepreneurship education in developing countries exploration on its necessity in the construction program', Journal of Engineering, Design and Technology, 6(2):178189.
McGee, J.E., Peterson, M., Mueller, S.L. \& Sequeira, J.M. 2009. 'Entrepreneurial self-efficacy: refining the measure', Entrepreneurship Theory \& Practice, 33:965-988.

McMullen, J.S. \& Shepherd, D.A. 2002. 'Regulatory focus and entrepreneurial intention: action bias in the recognition and evaluation of opportunities.' In: Bygrave, W.D. et al. (Eds.). Frontiers of entrepreneurship research. Babson College: Babson Park.

Meek, W.R., Pacheco, D.F. \& York, J.G. 2010. 'The impact of social norms on entrepreneurial action: Evidence from the environmental entrepreneurship context', Journal of Business Venturing, 25:493-509.

Mueller, S.L. \& Thomas, A.S. 2000. 'Culture and entrepreneurial potential: A nine country study of locus of control and innovativeness', Journal of Business Venturing, 16:51-75.

Peterman, N.E. \& Kennedy, J. 2003. 'Enterprise education: influencing students' perceptions of entrepreneurship', Entrepreneurship Theory and Practice, 28(2):129-145.

Pittaway, L. \& Cope, J. 2007. 'Entrepreneurship education: A systematic review of the evidence', International Small Business Journal, 25(5):479-510.

Rae, D. \& Carswell, M. 2000. 'Using a life-story approach in entrepreneurial learning: The development of a conceptual model and its implications in the design of learning experiences', Education + Training, 42(4/5):220227.

Scherer, R.F., Adams, J.S., Carley, S.S. \& Wiebe, F.A. 1989. 'Role model performance effects on development of entrepreneurial career preference', Entrepreneurship Theory and Practice, 13(3):53-71.

Segal, G., Borgia, D. \& Schoenfeld, J. 2005. 'The motivation to become an entrepreneur', International Journal of Entrepreneurial Behaviour and Research, 11(1):42-57.

Shane, S., Locke, E.A. \& Collins, C.J. 2003. 'Entrepreneurial motivation', Human Resource Management Review, 13:257-279.

Shapero, A. \& Sokol, L. 1982. 'The social dimensions of entrepreneurship'. In Kent, C., Sexton, D. \& Vesper, K. (Eds.). The encyclopaedia of entrepreneurship. New York: Prentice Hall. Pp.72-90.

Souitaris, V., Zerbinati, S. \& Al-Laham, A. 2007. 'Do entrepreneurship programs raise entrepreneurial intention of science and engineering students? The effect of learning, inspiration and resources', Journal of Business Venturing, 22:566-591. 
The World Bank. Report March. 2007. 'Malaysia and the knowledge economy: Building a world-class higher education system'.

[online]URL:worldbank.org/INTMALAYSIA/Resources/

Malaysia-Knowledge-Economy. Accessed 26.3.2011.

Trevelyan, R. 2011. 'Self-regulation and effort in entrepreneurial tasks', International Journal of Entrepreneurial Behaviour \& Research, 17(1):39 - 63.

Tumasjan, A. \& Braun, R. (In press.) 'In the eye of the beholder: How regulatory focus and self-efficacy interact in influencing opportunity recognition', Journal of Business Venturing.

Tyszka, T., Cieslik', J., Domurat, A. \& Macko, A. 2011. 'Motivation, self-efficacy, and risk attitudes among entrepreneurs during transition to a market economy', The Journal of Socio-Economics, 40:124-131.

Wilson, F., Kickul, J. \& Marlino, D. 2007. 'Gender, entrepreneurial self-efficacy, and entrepreneurial career intentions: Implications for entrepreneurship education', Entrepreneurship Theory and Practice, 31(3):387-401.

Wu, S. \& Wu, L. 2008. 'The impact of higher education on entrepreneurial intentions of university students in China', Journal of Small Business and Enterprise Development, 15(4):752-774.

Zhao, H., Seibert, S.E. \& Hills, G.E. 2005. 'The mediating role of self-efficacy in the development of entrepreneurial intentions', Journal of Applied Psychology, 90(6):12651272. 